\title{
RANCANG BANGUN APLIKASI PENCARIAN RUTE KOS-KOSAN SEKITAR UIN SUSKA RIAU BERBASIS ANDROID
}

\author{
${ }^{1}$ Medyantiwi Rahmawita, ${ }^{2}$ Gusfa Leo Firnando \\ 1,2Program Studi Sistem Informasi, Fakultas Sains dan Teknologi, UIN SUSKA Riau, \\ Jl. HR Soebrantas, KM. 18.5, No. 155, Simpang Baru, Pekanbaru, Indonesia, 28293. \\ Email: ${ }^{1}$ diantiwi0@gmail.com, ${ }^{2}$ gusfa.leo.firnando@students.uin-suska.ac.id.
}

\begin{abstract}
ABSTRAK
Rumah kos merupakan salah satu tempat tinggal bagi mahasiswa yang sedang menempuh ilmu dari luar kampung halaman. Berdasarkan 100 lembar kuesioner tentang pemilihan kos-kosan yang disebarkan kepada mahasiswa baru UIN Suska Riau, di dapatkan hasil 80 mahasiswa baru memilih kos-kosan yang dekat dengan kampus. Dikarenakan mahasiswa baru kurang mengetahui wilayah UIN Suska Riau serta harga, fasilitas dan layanan yang disedikan kos-kosan. Untuk itu diperlukan aplikasi pemetaan kos-kosan dengan berbagai detail, fasilitas, kapasitas tipe dan penentuan rute terpendek yang tepat agar dapat menekan waktu tempuh seminimal mungkin, serta dapat membantu dan memberikan kemudahan bagi mahasiswa baru dalam menemukan kos-kosan. Aplikasi yang dibangun menggunakan Location Based Service (LBS) memberikan layanan personalisasi kepada pengguna perangkat application mobile yang disesuaikan dengan lokasi mereka saat ini. Sehingga dengan memadukan antara application mobile dan algoritma Dijkstra diharapkan dapat mempermudah pengguna dalam melakukan pencarian lokasi kos-kosan dengan jarak yang terdekat dan dapat memberikan keputusan yang akurat. Berdasarkan hasil uji dengan metode User Acceptance Test (UAT) menunjukkan tingkat penerimaan pengguna sebesar $83,57 \%$.
\end{abstract}

Kata Kunci: algoritma dijkstra, application mobile, kos-kosan, LBS, mahasiswa

\section{A.PENDAHULUAN}

Kecamatan Tampan merupakan salah satu kecamatan dari 12 kecamatan yang ada di Kota Pekanbaru yang memiliki 9 kelurahan diantaranya Kelurahan Delima, Kelurahan Tuah Karya, Kelurahan Simpang Baru, Kelurahan Sidomulyo Barat, Kelurahan Air Putih, Kelurahan Tuah Madani, Kelurahan Bina Widya, Kelurahan Sialang Munggu dan Kelurahan Tobek Godang. Dalam penelitian ini dilakukan pegambilan data penelitian di 2 Kelurahan

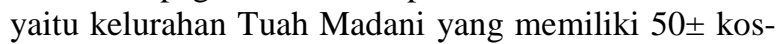
kosan dan Kelurahan Simpang Baru yang memiliki $100 \pm$ kos-kosan.

Rumah kos merupakan suatu tempat tinggal yang disewakan kepada pihak lain dengan fasilitas-fasilitas tertentu dengan harga yang lebih terjangkau. Rumah kos lebih akrab digunakan sebagai domilisi, karena kebanyakan rumah kos disewa dalam jangka waktu yang cukup lama dari pada hotel atau penginapan yang menggunakan hitungan hari. Rumah kos merupakan salah satu kebutuhan bagi para mahasiswa yang sedang menempuh ilmu di daerah lain dari luar kampung halaman, dan rumah kos merupakan kebutuhan utama. Pada umumnya mahasiswa yang memiliki prekonomian tinggi akan tinggal di sebuah apartemen atau guest house atau hotel, namun bagi mahasiswa yang memiliki kondisi ekonomi menengah kebawah, biasanya akan tinggal disebuah kamar tinggal yang biasanya di sebut dengan rumah kos, atau sering juga di sebut dengan kos-kosan [1].

Dari 100 lembar wawancara yang disebarkan kepada mahasiswa baru UIN Suska Riau di dapatkan hasil 80 mahasiswa baru tersebut memilih kos-kosan yang dekat dengan Kampus UIN Suska Riau. Mahasiswa baru ada dari luar daerah dan luar negeri untuk mencari tempat tinggal yaitu kos-kosan yang ada di sekitar UIN Suska Riau khususnya kecamatan tampan. Sementara itu mahasiswa baru yang tidak mengetahui wilayah lokasi kos-kosan harus mencari informasi tentang kos-kosan terlebih dahulu kemudian berkeliling wilayah untuk mencari lokasi tempat kos yang kosong. Masalah yang kedua mahasiswa sering kebingungan dalam mencari tempat kos yang pas, ideal, nyaman, fasilitas yang tersedia dan dengan harga yang sesuai, dan juga beberapa mahasiswa tidak memiliki kendaraan untuk pergi ke kampus. Oleh karena itu mahasiswa memilih kos terdekat dari kampus. Jika jarak semakin pendek, maka waktu yang dibutuhkan mahasiswa untuk sampai ke kampus lebih sedikit. Namun, jika jarak antara kos-kosan ke kampus semakin jauh, semakin banyak pula waktu dan biaya yang dibutuhkan.

Dengan ketersediaan informasi yang sangat terbatas, mahasiswa cenderung tidak memiliki informasi akurat dan relevan mengenai lokasi yang memiliki kos-kosan yang sesuai dengan kriteria. 
Untuk itu diperlukan pemetaan kos-kosan dengan menampilkan informasi harga, detail, fasilitas, kapasitas tipe, dan penentuan rute terdekat yang dapat menekan waktu tempuh seminimal mungkin. Berdasarkan permasalahan di atas untuk mendapatkan kos-kosan terdekat mahasiswa harus bisa memaksimalkan waktu dan jarak tempuh dari kos ke kampus UIN Suska Riau. Maka dibutuhkan aplikasi untuk membantu mahasiswa baru agar cepat dan mudah mendapatkan kos-kosan yang terdekat dari kampus.

Aplikasi yang dibangun menggunakan Location Based Service (LBS) yang memberikan layanan personalisasi kepada pengguna perangkat bergerak aplication mobile yang disesuaikan dengan lokasi. LBS memberikan informasi kondisi lalu lintas saat ini, menambahkan informasi rute perjalanan, dan membantu menemukan lokasi wisata terdekat [2]. Dalam penelitian ini menggunakan algoritma Dijkstra yang dikembangkan oleh seorang ilmuwan komputer dari Belanda, Edsger Dijkstra. Algoritma Dijkstra merupakan sebuah algoritma rakus yang dipakai dalam pemecahan masalah jarak terpendek untuk sebuah graf berarah dengan bobot sisi yang bernilai tak negatif [3].

Tiap algoritma memiliki cara kerja yang berbedabeda dalam menentukan solusi paling optimal. Pemilihan penggunaan algoritma Dijkstra dikarenakan algoritma ini sangat efektif untuk menentukan rute terpendek. Pada algoritma Dijkstra ini memiliki setiap node yang sudah dilewati akan kembali dihitung ulang sehingga dapat menentukan mana yang terpendek [4], artinya solusi-solusi tersebut dibentuk dari solusi yang berasal dari tahap sebelumnya. Sehingga, dengan memadukan antara aplication mobile dan algoritma Dijkstra diharapkan dapat mempermudah pengguna dalam melakukan pencarian lokasi kos-kosan dengan jarak yang terdekat dan dapat memberikan keputusan yang lebih akurat.

Penelitian sebelumnya yang dilakukan oleh Fairuz Zulmy Mirza Sahada dan T. Sutojo yang berjudul "Aplikasi Pencarian Rute Gedung Udius, Kos-kosan dan Kuliner Menggunakan Metode Dijkstra Sekitar Universitas Dian Nuswantoro", program aplikasi peta rekomendasi ini dapat memberikan alternatif bagi user dalam membantu memberikan rute lokasi Gedung Udinus, kos-kosan dan kuliner yang ada disekitar Universitas Dian Nuswantoro Semarang. Penelitian selanjutnya oleh António Gusmão dkk yang berjudul "Sistem Informasi Geografis Pariwisata Berbasis Web Dan Pencarian Jalur Terpendek Dengan Algoritma Dijkstra" yang menghasilakan data jarak masing-masing rute. Nilai masing-masing jarak didapatkan dari pengukuran Google Earth. Serta hasil keluaran rute terpendek sistem yang didapatkan dari proses algoritma Dijkstra, dan penilitian yang dilakukan oleh Luthfi Fahronzi dengan judul "Aplikasi
Location Based Service (LBS) untuk Pencarian rute Terpendek Menggunakan Algoritma Dijkstra" Aplikasi berhasil menampilkan urutan daftar customer berdasarkan perhitungan algoritma Dijkstra dan kriteria yang digunakan untuk menentukan rute terpendek adalah jarak garis lurus antar lokasi. Selanjutnya Google Maps akan menampilkan rute jalan untuk menuju ke lokasi masing-masing customer, sehingga pada situasi tertentu aplikasi tidak dapat memberikan solusi rute dan jarak yang optimal.

Aplikasi berbasis android memang telah banyak dimanfaatkan pada saat sekarang ini. Tidak hanya membantu mempermudah mahasiswa dalam mencari tempat kos-kosan yang sesuai dengan kebutuhan, aplikasi berbasis android juga banyak memberikan kemudahan lainnya bagi mahasiswa seperti penelitian sebelumnya yang telah membangan aplikasi berbasis android untuk pencarian tempat olahraga di daerah Panam Pekanbaru Riau [9], bahkan aplikasi berbasis android juga sangat banyak membantu mempermudah proses pembelajaran lewat media interaktif dalam dunia pendidikan [10].

\section{B. Tinjauan Pustaka}

\section{B.1. Sistem Informasi Geografis (SIG)}

Sistem adalah entitas atau satuan yang terdiri dari dua atau lebih komponen atau subsistem (sistem yang lebih kecil) yang saling terhubung dan terkait untuk mencapai suatu tujuan. Komponen-komponen tersebut dapat berupa hardware maupun software [5]. Perangkat lunak (software) adalah program komputer yang terasosiasi dengan dokumentasi perangkat lunak seperti dokumentasi kebutuhan, model desain, dan cara penggunaan (user manual). Sistem perangkat lunak berarti sebuah sistem yang memiliki komponen berupa perangkat lunak yang memiliki hubungan satu sama lain untuk memenuhi kebutuhan pelanggan atau user [6].

\section{B.2. Tempat Kos}

Tempat kos merupakan suatu tempat tinggal yang disewakan kepada pihak lain dengan fasilitasfasilitas tertentu dengan harga yang lebih terjangkau daripada di hotel/penginapan. Tempat kos lebih akrab digunakan sebagai domilisi, karena kebanyakan tempat kos disewa dalam jangka waktu yang cukup lama dari pada hotel atau penginapan yang menggunakan hitungan hari. Istilah tempat kos sangatlah berdampingan dengan mahasiswa, karena pada umumnya tempat kos disewakan untuk mahasiswa walaupun tidak jarang juga tempat kos yang disewakan untuk umum. Tempat kos sangatlah bermacam-macam dari cara penyewaannya, fasilitasfasilitas dan harga yang bervariasi. Tempat kos merupakan suatu investasi yang cukup menjanjikan yang dimana kita dapat menghitung biaya perbulan 
Jurnal Ilmiah Rekayasa dan Manajemen Sistem Informasi, Vol. 6, No. 1, Februari 2020, Hal. 16-25

e-ISSN 2502-8995, p-ISSN 2460-8181

dengan yang dihasilkan disetiap bulannya [7]. Biasanya alasan memilih tempat kos sebagai tempat tinggal adalah sebagai berikut:

1. Studi/kuliah dalam jangka pendek ataupun lama.

2. Biaya yang terjangkau dibandingkan daripada ke hotel/penginapan.

3. Tempat kos sudah sangat banyak dan mudah dijangkau yaitu yang terdapat dilokasi kampus, perkantoran, dan sekolah.

4. Cara penyewaan yang bervariasi, bergantung kebutuhan. Perhari, perbulan, perenam bulan atau pertahun.

\section{B.3. Algoritma Dijkstra.}

Ditemukan oleh seorang ilmuan komputer Belanda, Edsger W. Djikstra pada tahun 1956 dan diterbitkan pada tahun 1959 yang merupakan salah satu varian bentuk algoritma populer dalam pemecahan persoalan yang terkait dengan masalah optimasi dan bersifat sederhana. Algortima ini menyelesaikan masalah mencari sebuah lintasan terpendek (sebuah lintasan yang mempunyai panjang minimum) dari vertex a ke vertex $\mathrm{z}$ dalam graph berbobot. Bobot tersebut adalah bilangan positif, jadi tidak dapat dilalui oleh node negatif. Namun jika terjadi demikian, maka penyelesaian yang diberikan adalah infiniti.

\section{B.4. Waterfall}

Metode penelitian ini melakukan pendekatan secara sistematis dan urut mulai dari level kebutuhan sistem lalu menuju ke tahap analisis, desain, coding, testing/verification, dan maintenance. Disebut dengan waterfall karena tahap demi tahap yang dilalui harus menunggu selesainya tahap sebelumnya dan berjalan berurutan. Sebagai contoh tahap desain harus menunggu selesainya tahap sebelumnya yaitu tahap requirement [8].

\section{C.Metodologi Penelitian}

Metode penelitian yang peneliti lakukan dalam penelitian ini dapat dijabarkan seperti pada Gambar 1.

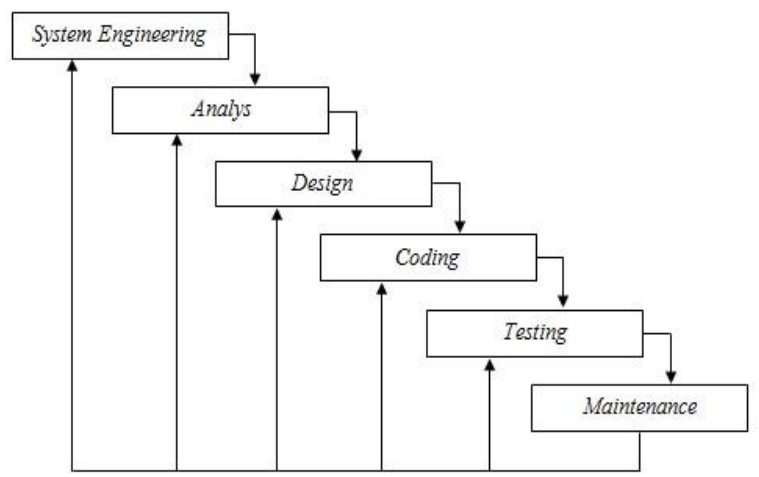

Gambar 1. Alur proses waterfall

\section{C.1. Tahap Perencanaan}

Pada tahap perencanaan, ada beberapa tahapan yang harus direncanakan saat melakukan penelitian, tahap yang dilakukan adalah:

\section{Identifikasi Masalah}

Rumah kos atau kos-kosan merupakan suatu tempat tinggal yang disewakan kepada pihak lain dengan fasilitas-fasilitas tertentu dengan harga yang lebih terjangkau. Rumah kos lebih akrab digunakan sebagai domilisi, karena kebanyakan rumah kos disewa dalam jangka waktu yang cukup lama dari pada hotel atau penginapan yang menggunakan hitungan hari. Rumah kos merupakan salah satu kebutuhan bagi para mahasiswa yang sedang menempuh ilmu di daerah lain dari luar kampung halaman, dan rumah kos merupakan kebutuhan utama bagi para mahasiswa, sering kali orang-orang yang mencari kos-kosan mengalami banyak kendala diantarannya pengetahuan informasi akan kos itu sendiri dan juga keberadaan lokasi kos-kosan, Selain itu pencari kos-kosan mayoritas adalah mahasiswa yang baru pindah ke kota yang belum mengenal wilayah tersebut dengan baik sehingga informasi yang lengkap mengenai lokasi rumah kos mutlak dibutuhkan.

\section{Menentukan Topik}

Hal yang pertama dilakukan untuk menentukan topik permasalahan yang akan diangkat pada penelitian ini adalah membuat sebuah Aplikasi Location Based Service Pencarian Rute Koskosan Sekitar UIN Suska Riau Berbasis Android.

\section{Menentukan Objek Penelitian}

Setelah topik ditentukan, maka selanjutnya adalah menentukan objek penelitian yaitu koskosan yang berada di sekitar UIN Suska Riau dan Kecamatan Tampan.

\section{Menentukan Tujuan Penelitian}

Tujuan dari penelitian ini yaitu menghasilkan aplikasi location based service pencarian rute kos-kosan sekitar UIN Suska Riau berbasis android untuk memudahkan pencarian rute koskosan bagi mahasiswa baru dan menghasilkan sistem yang bermanfaat.

\section{C.2. Tahap Pengumpulan Data}

Pada tahap ini data beserta alat pengumpulan data ditentukan. Selanjutnya dilakukan pengumpulan data. Tahap ini berisi tentang penentuan data primer dan data sekunder dengan menggunakan teknik pengumpulan data yaitu:

\section{Observasi}

Observasi yang dilakukan pada penilitian ini adalah dengan turun langsung ke lokasi dimana kos-kosan itu berada di Kecamatan Tampan, lalu 
dari hasil pengamatan akan dibuat gambaran sistem yang akan dibangun.

\section{Wawancara}

Wawancara yang dilakukan yaitu mewawancarai pemilik kos-kosan untuk mengetahui informasi mengenai detail kos, fasilitas, serta pelayanan yang akan diberikan kepada calon penyewa koskosan. Peneliti juga melakukan wawancara kepada calon penyewa kos-kosan yaitu mahasiwa baru UIN Suska Riau untuk mengetahui bagaimana proses pencarian kos-kosan dan permasalahan yang terjadi.

\section{Studi Pustaka}

Tahap studi pustaka dilakukan dengan membaca buku-buku serta jurnal yang berhubungan dengan topik penilitian. Tahap ini berguna untuk menambah referensi data sebagai pendukung permasalahan penilitian ini.

Setelah memahami dan meneliti permasalahan, selanjutnya mengumpulkan data-data yang berhubungan dengan penelitian ini. Data-data yang dibutuhkan yaitu data primer dan data sekunder. Data Primer adalah data yang diperoleh secara langsung dari objek penelitian, seperti data profil kos-kosan, detail kos, fasilitas dan deskripsi. Data Sekunder adalah data yang diperoleh secara tidak langsung atau data yang diperoleh selain dari objek penelitian. Dalam hal ini terlebih dahulu data dikumpulkan yang didapat dari jurnal, buku, internet maupun literatur yang berhubungan erat dengan topik penelitian. Pengumpulan data ini dilakukan dengan melakukan studi literatur.

\section{C.3. Analisa dan Perancangan Sistem}

Setelah data dikumpulkan, tahap selanjutnya adalah analisa dan perancangan sistem yang merupakan tahapan paling penting dalam penilitian ini. Pada tahap ini akan dibangun menggunakan metode Object Oriented Analysisand Design (OOAD). Adapun kegiatan yang dilakukan dalam tahapan ini adalah sebagai berikut:

1. Analisa Sistem yang Sedang Berjalan.

Tahap ini dilakukan dengan mengetahui sistem yang sedang berjalan saat ini untuk kemudian diteliti.

\section{Analisa Sistem Baru}

Tahap ini dilakukan setelah meneliti sistem yang sedang berjalan dan menemukan beberapa kelemahan dan kekurangan, kemudian barulah dibuatkan sebuah rancangan sistem baru yang dapat meminimalisir kelemahan dan kekurangan yang ada pada sistem lama atau sistem yang sedang berjalan.

3. Desain Pemodelan Sistem dengan UML

Pada tahap ini melakukan pemodelan sistem baik sistem yang sedang berjalan maupun sistem baru dengan menggunakan tools dari metode OOAD yaitu UML.

a) Use case diagram adalah bagian penting untuk memvisualisasikan, menspesifikasikan, dan mendokumentasikan kebutuhan perilaku sistem. Use case diagram digunakan untuk menjelaskan kegiatan apa saja yang dapat dilakukan oleh pengguna sistem yang sedang berjalan.

b) Sequence diagram menggambarkan interaksi dari objek yang disusun dalam suatu urutan waktu atau kejadian tertentu dalam suatu proses.

c) Activity diagram merupakan Sebuah keadaan awal (start state) dan keadaan akhir (end state), transisi yang menggambarkan keadaan mengikuti suatu keadaan lainnya, batang penyelaras (synchronization bar) yang memperlihatkan sub alur parallel, aktivitasaktivitas yang menggambarkan satu tahapan dalam workflow tersebut, keputusan, elemen yang menyediakan pilihan alur dalam workflow dan Swimlane yang menjelaskan pemeran bisnis yang bertanggung jawab terhadap aktivitas yang dikandungnya.

\section{Merancang Interface Sistem}

Setelah di buat pemodelan sistem dengan UML, tahap selanjutnya adalah merancang interface yang mudah dimengerti serta sesuai dengan kebutuhan pengguna.

\section{C.4. Tahap Implementasi}

Tahap ini terdiri dari dua kegiatan yaitu:

\section{Pengodingan}

Pada tahap ini melakukan pengodingan sistem atau proses pembuatan aplikasi Find Kost.

\section{Pengujian Sistem}

Setelah melalui tahap pengodingan selanjutnya akan dilakukan tahap pengujian, tahap pengujian ini di lakukan dengan tujuan untuk menjamin sistem yang di buat sesuai dengan hasil analisis dan perancangan serta menghasilkan satu kesimpulan apakah sistem tersebut sesuai dengan yang di harapkan. Pengujian sistem di lakukan setelah sistem selesai. Tahap pengujian dilakukan dengan menggunakan metode Blackbox testing dan UAT.

\section{C.5. Tahap Dokumentasi}

Tahap penulisan laporan merupakan tahapan akhir dalam kegiatan penelitian ini yang mendokumentasikan semua dari hasil yang telah diperoleh. Dari dokumentasi penelitian ini melahirkan sebuah jurnal yang dipublikasikan secara umum untuk kepentingan penelitian-penelitian berikutnya yang terkait. 
Jurnal Ilmiah Rekayasa dan Manajemen Sistem Informasi, Vol. 6, No. 1, Februari 2020, Hal. 16-25

e-ISSN 2502-8995, p-ISSN 2460-8181

\section{HASIL DAN PEMBAHASAN}

\section{D.1. Analisa Sistem Berjalan}

Analisa sistem yang sedang berjalan merupakan langkah utama yang harus dilaksanakan sebelum memberikan sebuah sistem usulan, berdasarkan analisa ini nantinya akan dijadikan alasan kenapa dibutuhkannya sebuah sistem usulan. Analisa sistem berjalan dapat berupa identifikasi permasalahan yang terjadi dan harus segera diselesaikan ataupun dapat berupa manfaat yang diharapkan oleh pihak mahasiswa atau user dan pihak pemilik kos-kosan terhadap pengadaan sistem tersebut.

Pencarian rumah kos-kosan sebelumnya yaitu calon penyewa rumah kos-kosan melakukan survey lokasi dimana letak rumah kos-kosan tersebut, mahasiswa yang akan menggunakan jasa rumah koskosan harus mendatangi tempat kos-kosan secara langsung satu persatu untuk mendapatkan informasi tentang detail kos seperti harga kos, jenis kos-kosan putra atau putri, fasilitas apa yang tersedia, dan yang paling penting jarak tempu yang diperlukan dari koskosan ke kampus UIN Suska Riau.

\section{D.2. Identifikasi Permasalahan}

Berdasarkan observasi yang dilakukan pada rumah kos-kosan, identifikasi masalah yang dapat dilakukan adalah permasalahan dalam proses penyampaian informasi yang berkaitan dengan detail kos, fasilitas serta layanan kos-kosan.

Saat ini alur proses mahasiswa atau calon penyewa rumah kos-kosan untuk mendapatkan informasi mengenai detail, fasilitas serta layanan koskosan masih belum efektif. Informasi didapatkan oleh mahasiswa atau calon penyewa dengan cara mendatangi langsung ke lokasi kos-kosan dan menanyakan secara langsung kepada pihak pemilik kos-kosan. Dengan kondisi seperti ini informasi tentang kos-kosan tidak akan diketahui oleh mahasiswa secara luas yang mengakibatkan kurangnya penyampaian informasi yang akurat dan juga minat terhadap kos-kosan tersebut.

Informasi mengenai kos-kosan saat ini masih terbatas, seperti list kos-kosan di surat kabar atau koran, dan juga informasi nomor hp pemilik kos-kosan yang terdapat di selembaran kertas yang ditempel pada pohon sekitar jalan, rumah makan sekitar kos dan kampus UIN Suska Riau.

Berdasarkan masalah yang dihadapi tersebut, maka diusulkan sebuah aplikasi location based service pecarian rute kos-kosan sekitar UIN Suska Riau. Adapun sistem yang akan dibangun meliputi sistem informasi kos-kosan berbasis mobile application untuk mengetahui lokasi dan rute kos-kosan terdekat dari kampus UIN Suska Riau.

\section{D.3. Analisa Sistem Usulan}

Sistem usulan yang dirancang dapat memudahkan pihak pemilik kos-kosan dalam mengelola data kos-kosan, data fasilitas dan data detail kos-kosan kemudian diintegrasikan dengan data mahasiswa. Sehingga memudahkan bagi mahasiswa mengetahui lokasi, rute, detail, fasilitas dan jenis koskosan secara realtime.

Dari hasil definisi sistem yang telah diuraikan di atas, maka aplikasi yang diusulkan adalah membangun sebuah aplikasi location based service pecarian rute kos-kosan sekitar UIN Suska Riau. Gambar 2 dan Tabel 1 merupakan use case diagram dan Daftar aktor yang merupakan gambaran dari sistem usulan. Aplikasi ini akan memberikan manfaat kepada mahasiswa khususnya mahasiswa baru sebagai pengguna layanan tersebut. Ada empat manfaat yang didapat dari penerapan sistem ini, yaitu:

1. Membantu pihak pemilik kos-kosan dalam mempromosikan atau mempublis informasi tentang kos-kosan mereka.

2. Membantu pemilik kos-kosan dalam menyampaikan informasi mengenai layanan koskosan seperti detail, fasilitas dan jenis kos-kosan.

3. Membantu mahasiswa khususnya mahasiswa baru dalam mengakses informasi tentang koskosan.

4. Membantu mahasiswa khususnya mahasiswa baru mengetahui rute dan lokasi kos-kosan yang terdekat dari Kampus UIN Suska Riau.

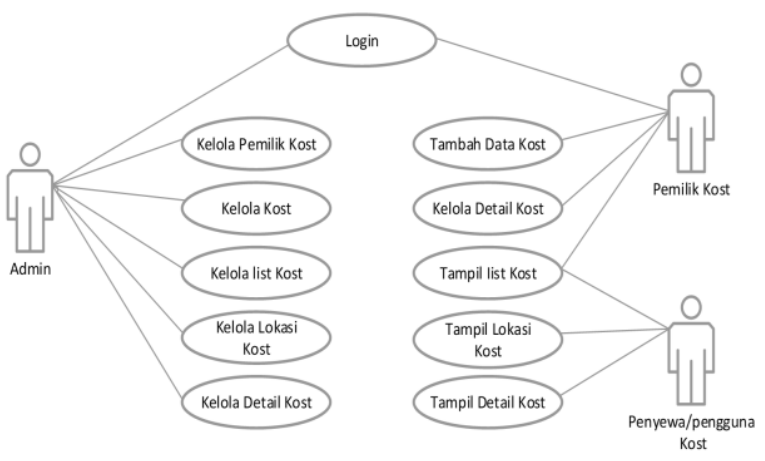

Gambar 2. Use case diagram aplikasi Find Kost (Sumber: Data Primer, 2019)

Tabel 2. Daftar Aktor

\begin{tabular}{|c|c|c|}
\hline No. & Aktor & Keterangan \\
\hline 1. & Administrator & $\begin{array}{l}\text { Meliputi: } \\
\text { 1. Masuk ke sistem. } \\
\text { 2. Dapat mengelola pemilik kos. } \\
\text { 3. Dapat kelola kos seperti melihat dan } \\
\text { menghapus data kos-kosan. } \\
\text { 4. Dapat melakukan tambah, edit, } \\
\text { hapus lokasi kos. } \\
\text { 5. Dapat melihat dan menghapus detail } \\
\text { kos. }\end{array}$ \\
\hline
\end{tabular}




\begin{tabular}{lll}
\hline 2. & Pemilik Kos & Meliputi: \\
& & 1. Masuk ke aplikasi \\
& 2. Dapat melakukan tambah, edit, dan \\
& hapus data kos-kosan. \\
& 3. Dapat mengelola detail kos, tambah, \\
& edit dan hapus \\
& & 4. Dapat melihat list kos-kosan. \\
& & Meliputi: \\
3. Penyewa atau & 1. Masuk ke aplikasi \\
& 2. Dapat melihat list kos-kosan. \\
& 3. Dapat melihat lokasi kos-kosan. \\
& 4. Dapat melihat detail kos-kosan. \\
\hline
\end{tabular}

(Sumber: Data Olahan, 2019)

\section{D.4. Implementasi Sistem}

Tahapan ini merupakan tahap implementasi hasil perancangan interface Yang telah dibuat pada tahap detail design. Dalam aplikasi location based service pencarian rute kos-kosan sekitar UIN Suska Riau user/pengguna menggunakan Android dan database MySQL.

1) Tampilan halaman menu registrasi.

Tampilan ini merupakan tampilan registrasi mobile application yang nantinya akan digunakan oleh user, yaitu pemilik kos. Untuk dapat login, pemilik kos terlebih dahulu mendaftar menggunakan alamat email. Tampilan registrasi dapat dilihat pada Gambar 3.

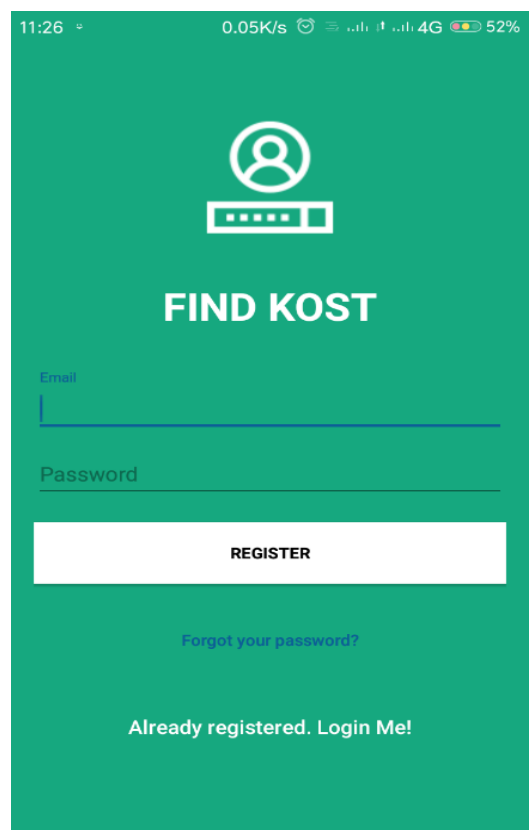

Gambar 3. Tampilan halaman registrasi aplikasi

2) Tampilan halaman menu login.

Tampilan ini merupakan tampilan login yang nantinya akan digunakan oleh user, yaitu pemilik kos. Setelah registrasi, pemilik kos dapat login dengan menggunakan username dan password yang sebelumnya sudah di isi saat registrasi. Tampilan halaman login dapat dilihat pada Gambar 4.

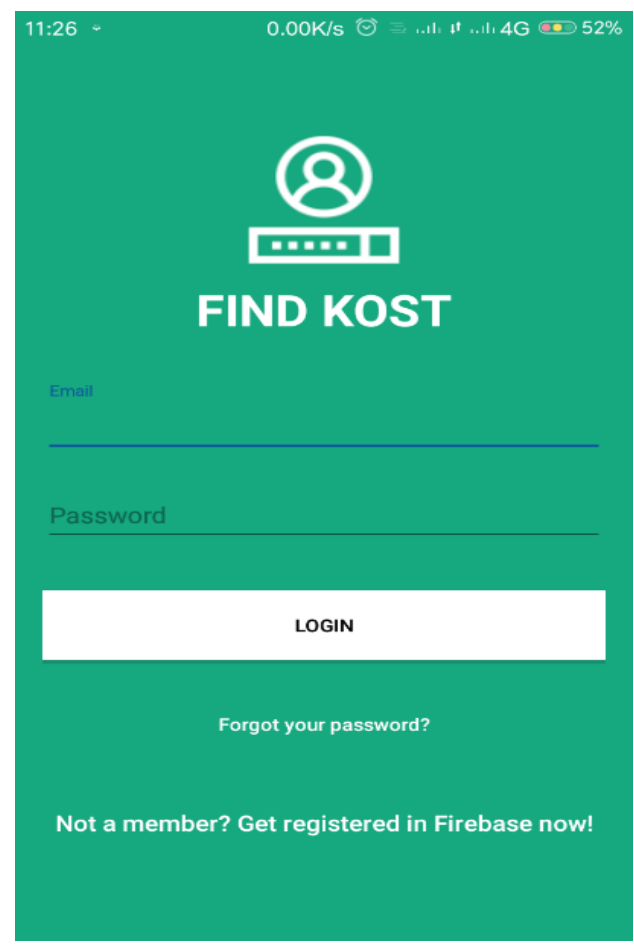

Gambar 4. Tampilan menu login

3) Tampilan halaman utama Find Kost.

Halaman ini merupakan tampilan yang berisi beberapa menu seperti list kos, find route, profile, about dan maps view. Ditampilan halaman utama ini memiliki menu pencarian dan filter kos. Tampilan halaman utama find kost dapat dilihat pada Gambar 5.
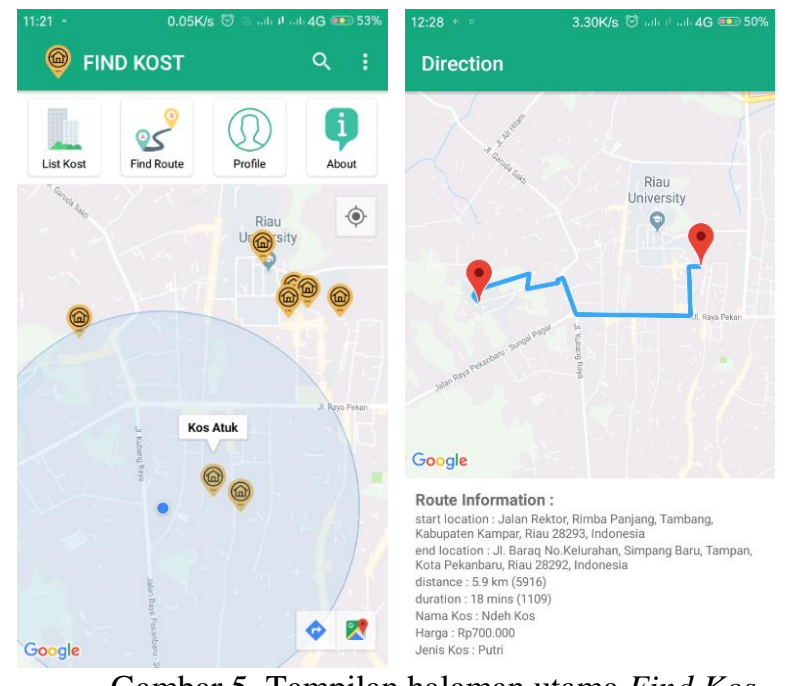

Gambar 5. Tampilan halaman utama Find Kos

4) Tampilan halaman menu list kos.

Tampilan ini merupakan tampilan menu list kos yang berisi daftar kos serta informasi tentang detail kos dan rute lokasi kos-kosan. Tampilan halaman menu list kos dapat dilihat pada Gambar 6. 
Jurnal Ilmiah Rekayasa dan Manajemen Sistem Informasi, Vol. 6, No. 1, Februari 2020, Hal. 16-25

e-ISSN 2502-8995, p-ISSN 2460-8181
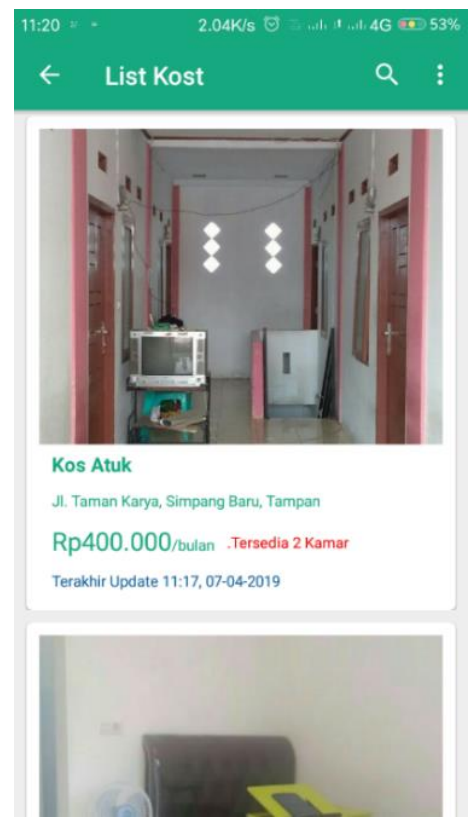

Gambar 6. Tampilan halaman menu list kos

5) Tampilan halaman menu search.

Halaman ini akan menyediakan tombol pencarian yang akan mempermudah user dalam mencari koskosan yang diinginkan. Tampilan halaman menu search dapat dilihat pada Gambar 7.

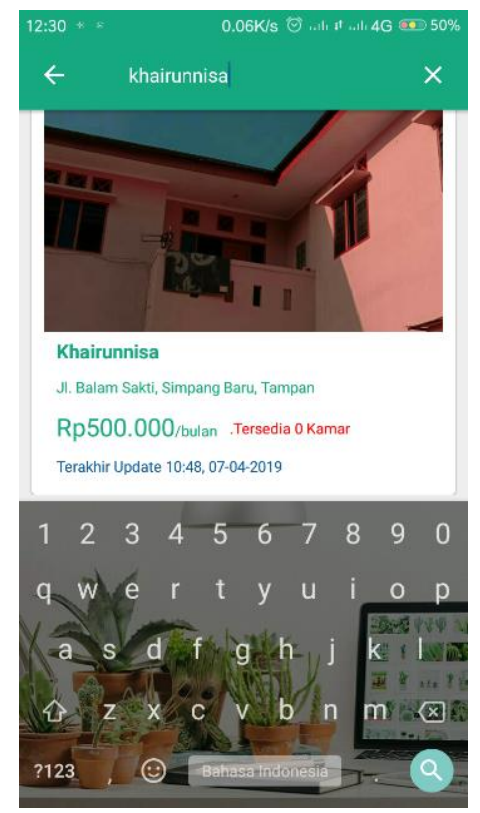

Gambar 7. Tampilan halaman menu search.

6) Tampilan halaman menu filter.

Tampilan halaman ini menampilkan kos-kosan yang ingin dicari oleh user sesuai dengan harga dan jenis kos. Tampilan halaman menu filter dapat dilihat pada Gambar 8.

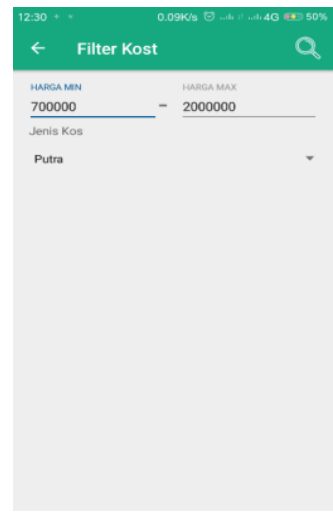

Gambar 8. Tampilan halaman menu filter

7) Tampilan halaman detail kos (user).

Halaman ini menampilkan detail kos yang ingin dilihat oleh user, serta informasi tentang rute lokasi kos-kosan. Tampilan halaman detail kos dapat dilihat pada Gambar 9.
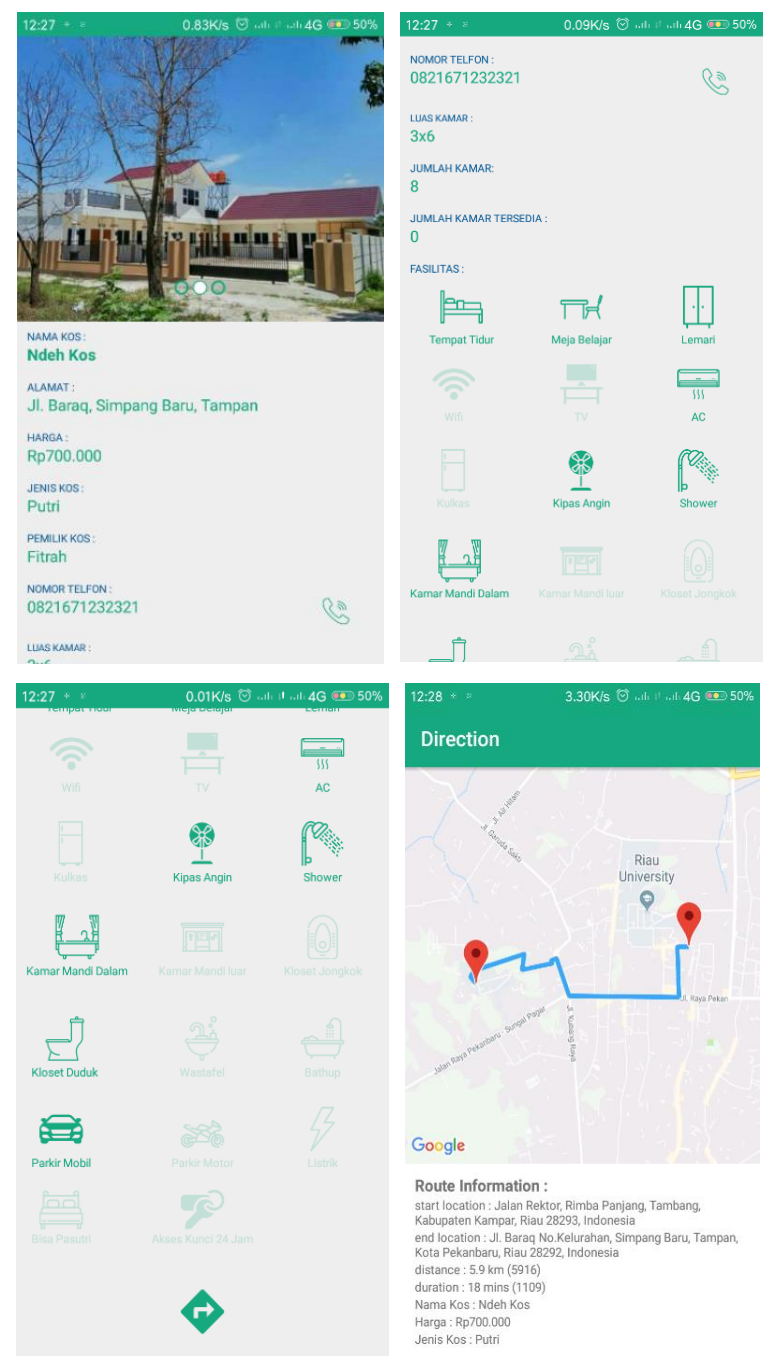

Gambar 9. Tampilan halaman detail kos (user) 
8) Tampilan halaman find route.

Tampilan halaman menu ini berisi daftar koskosan yang telah dihitung oleh algoritma Dijkstra kemudian direkomendasikan dengan urutan rute koskosan yang paling dekat dengan titik awal. User juga bisa mencari dan melihat rute kos-kosan mana yang paling dekat yang akan dituju.Tampilan menu find route dapat dilihat pada Gambar 10.
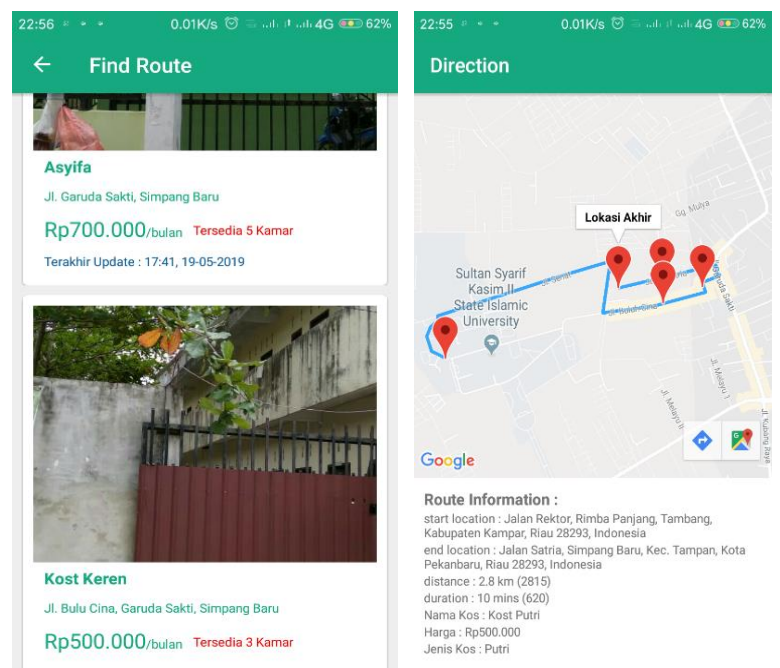

Gambar 10. Tampilan halaman find route

9) Tampilan halaman menu profile.

Tampilan ini akan memberikan hak akses untuk pemilik kos yaitu melakukan tambah, edit dan hapus kos sesuai dengan akun pemilik kos miliki yang telah diregistrasi dan melakukan login terlebih dahulu. Tampilan halaman menu profile dapat dilihat pada Gambar 11.

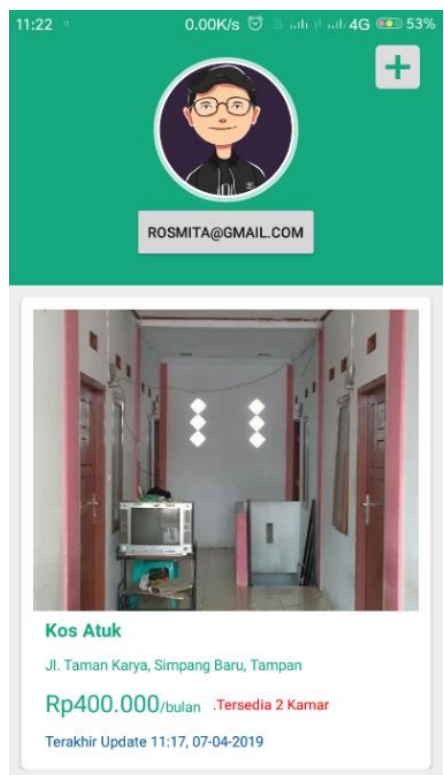

Gambar 11. Tampilan halaman menu profile
10) Tampilan halaman menu tambah kos.

Tampilan ini merupakan tampilan menu tambah data kos, dimana pada menu ini akan menyediakan form tambah data kos yang dapat di isi oleh pemilik kos. Tampilan menu tambah kos dapat dilihat pada Gambar 12.

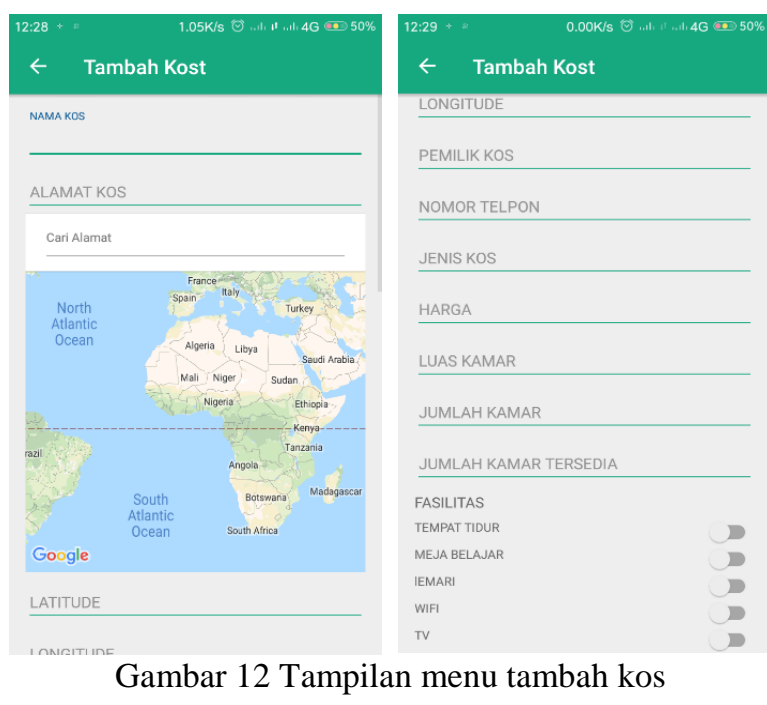

11) Tampilan halaman detail kos (pemilik kos).

Halaman ini menampilkan detail kos yang ingin dilihat oleh pemilik kos tentang detail kos yang dimiliki pemilik kos, sehingga pemilik kos bisa melihat dibagian mana informasi yang salah atau yang ingin diperbaiki. Tampilan halaman detail kos dapat dilihat pada Gambar 13.

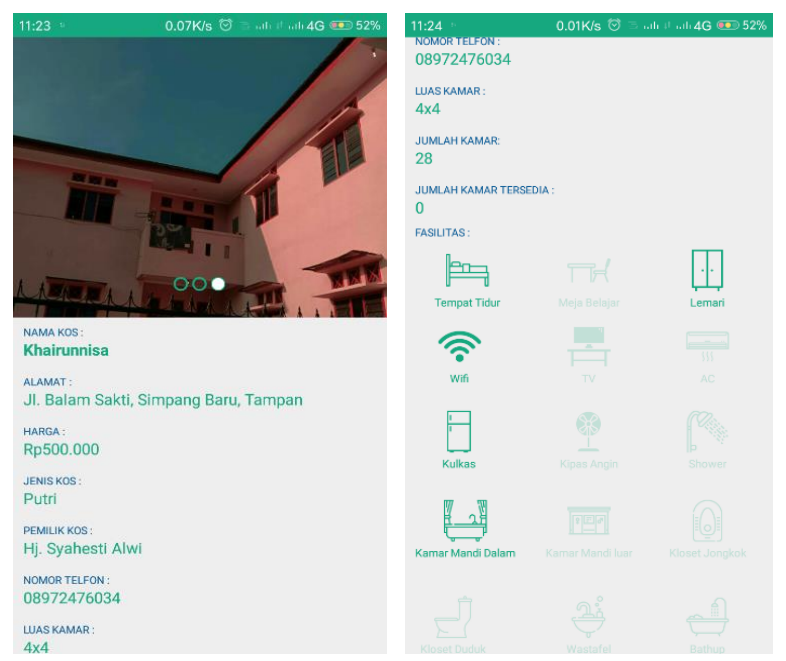

Gambar 13. Halaman detail kos (pemilik kos)

12) Tampilan halaman menu tambah foto.

Tampilan ini merupakan tampilan yang menyediakan tombol tambah foto dan upload untuk menambah foto kos-kosan. Tampilan menu tambah foto dapat dilihat pada Gambar 14. 
Jurnal Ilmiah Rekayasa dan Manajemen Sistem Informasi, Vol. 6, No. 1, Februari 2020, Hal. 16-25

e-ISSN 2502-8995, p-ISSN 2460-8181

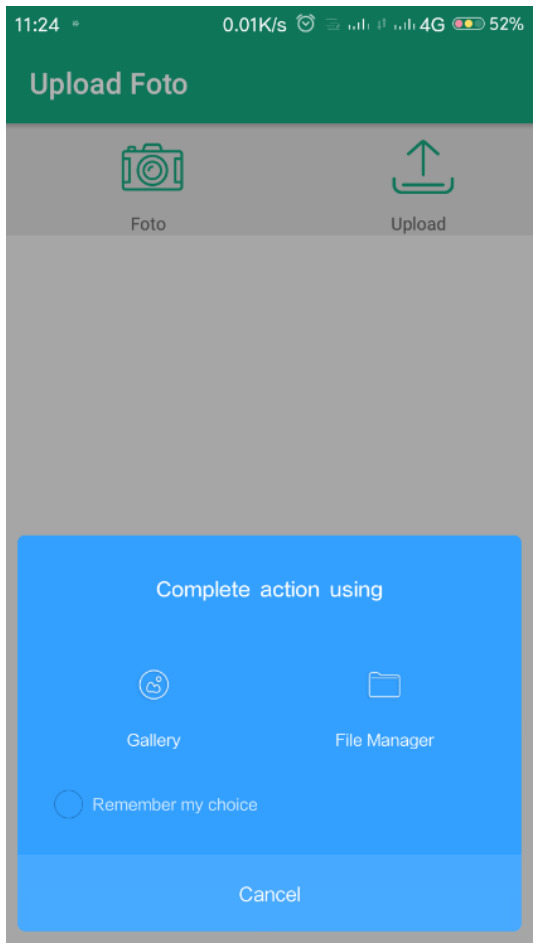

Gambar 14. Tampilan halaman menu tambah foto

13) Tampilan halaman menu edit.

Tampilan ini merupakan tampilan menu edit, menu ini akan menyediakan form edit yang bisa diganti dengan data baru sesuai update data kos oleh pemilik kos-kosan. Tampilan menu edit dapat dilihat pada Gambar 15.

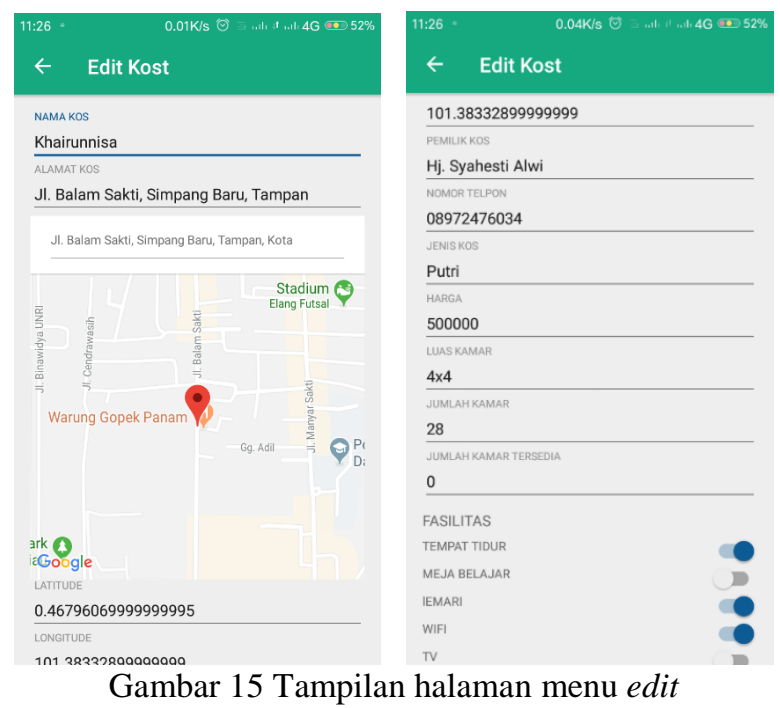

14) Tampilan halaman menu hapus.

Tampilan ini merupakan tampilan hapus, dimana pemilik kos memiliki akses untuk menghapus data kos-kosan yang pemilik kos miliki. Tampilan menu hapus dapat dilihat pada Gambar 16.

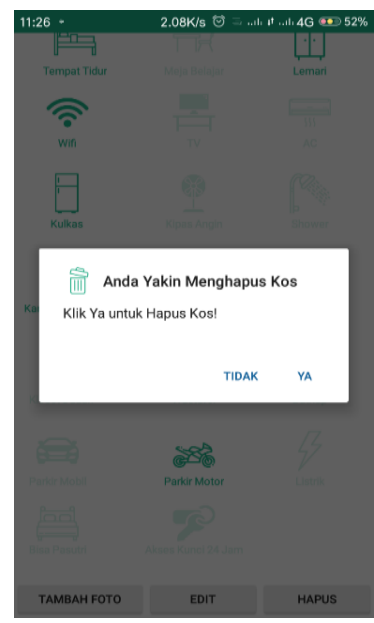

Gambar 16. Tampilan halaman menu hapus

15) Tampilan halaman menu about.

Tampilan ini merupakan informasi tentang aplikasi yang telah dibuat. Tampilan menu about dapat dilihat pada Gambar 17.

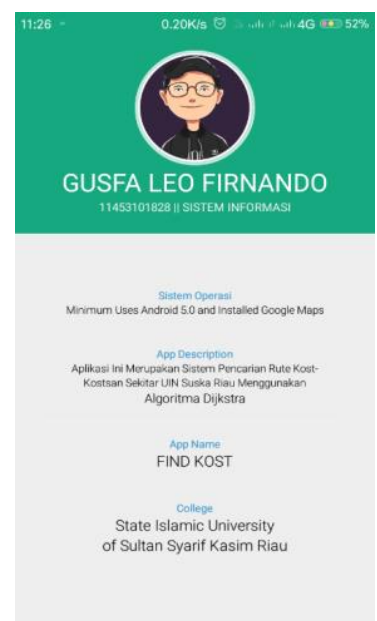

Gambar 17. Tampilan halaman menu about

\section{E. KESIMPULAN}

Berdasarkan penelitian yang telah dilakukan pada kos-kosan sekitar UIN Suska Riau dan Kecamatan Tampan, maka dapat diambil kesimpulan, yaitu:

1. Penelitian ini berhasil membangun aplikasi pencarian kos-kosan berbasis android yang terintegrasi melalui database.

2. Dalam aplikasi Find Kost algoritma Dijkstra telah berhasil memberikan rekomendasi rute marker kos-kosan yang dilewati, sehingga memberikan rekomendasi pilihan kos-kosan yang sesuai dengan kriteria mahasiswa/i cari.

3. Hasil user acceptance test pada 20 responden menunjukkan fitur-fitur sistem yang dibuat tingkat penerimaan pengguna sebesar $83,57 \%$. 
Ada beberapa saran yang perlu disampaikan, dengan harapan akan menjadi suatu masukan yang bermanfaat, yaitu:

1. Untuk penelitian selanjutnya diharapkan dapat dikembangkan di kota Pekanbaru dengan jangkauan yang lebih luas.

2. Untuk penelitian selanjutnya agar dapat menambahkan fasilitas umum yang berada disekitar kos-kosan dan menambahkan fitur-fitur seperti message, kolom komentar untuk penyewa kos dan pemilik kos.

3. Perlu pengembangan interface agar tampilan aplikasi lebih menarik lagi dan lebih bagus.

\section{REFERENSI}

[1] Dadi Rosadi dan Febi Oktarista Andriawan, ( Juni, 2016) Aplikasi Sistem Informasi Pencarian Tempat Kos Dikota Bandung Berbasis Android. Jurnal Computech \& Bisnis. Edisi 10, No. 1. hal. 50

[2] Putra, Akbar Nuzul. (2014), Aplikasi Wisata Kota Bandung Menggunakan Metode Location Based Service (LBS) Pada Android. Bandung: Politeknik Telkom.

[3] Kadir Abdul. (2010). Pengenalan Algoritma. Yogyakarta: Penerbit Andi.

[4] Lubis, Henny Syahriza, (2009), Perbandingan Algoritma Greedy dan Dijkstra Untuk
Menentukan Lintasan Terpendek. Skripsi Universitas Sumatera Utara.

[5] Tantra, R. (2012). Manajemen Proyek Sistem Informasi. Yogyakarta: Penerbit Andi.

[6] Shalahuddin, M. Rosa A.S, (2016). Rekayasa Perangkat Lunak Terstruktur Dan Berorientasi Objek. Bandung, Informatika.

[7] Abidin Bakti, Prasetyaningrum Ira, dan Karlita Tita. (2012). "Sistem Informasi Rumah Kos Online Berbasis Web dan Messaging”, Mahasiswa Jurusan Teknik Informatika. Politeknik Elektronika Negeri Surabaya. Institut Teknologi Sepuluh Nopember.

[8] Youssef Bassil, (2012), A Simulation Model for the Waterfall Software Development Life Cycle. Internaional J. Eng. Technol., vol. 2, no. 5, p. 2.

[9] Ameldi, Roni, dan Tengku Khairil Ahsyar. "Sistem Informasi Reservasi Lapangan Futsal Berbasis Android Pada Lapangan Futsal.” Jurnal Ilmiah Rekayasa dan Manajemen Sistem Informasi 4.1 (2018): 81-90.

[10] Alfikri, Ivan, dan Tengku Khairil Ahsyar. "Media Pembelajaran Interaktif Seni Origami Berbasis Animasi Untuk Anak Tunagrahita Sedang." Jurnal Ilmiah Rekayasa dan Manajemen Sistem Informasi 3.2 (2017): 50-60. 